\title{
Klumme: Putin har overspillet sin hånd
}

\section{Af Michael Ehrenreich}

Ledelsen i Kreml har med annekteringen af Krim og presset mod Ukraine udløst en vedvarende krise i forhold til Vesten. På kort sigt ligner Putin en vinder, men i et længere perspektiv bliver der en meget høj pris at betale.

Præsident Putin har haft nogle travle uger på kontoret, og det er ikke småting, han har nået at få fra hånden. Ruslands udenrigspolitiske situation er grundlæggende ændret. Men det er svært at se, at de enkelte elementer skulle være til landets umiddelbare fordel, særligt når man anskuer dem i den traditionelle russiske optik af mistænksomhed overfor Vesten:

- Europa og USA er pludselig rykket tættere sammen. Efter lang tids gnidninger som følge af aflytningsskandalen og uenighed om bekæmpelsen af den økonomiske krise er der nu helt andre boller på suppen.

- NATO har med ét slag fået nyt liv. Mens der drosles ned for engagementet i Afghanistan, tegner der sig igen vigtige opgaver tættere på. Helt i modsætning til perspektiverne for bare få måneder siden.

- EU-landene er begyndt at føre udenrigspolitik sammen. Det sker med stor vanskelighed og megen tøven, men det sker. De 28 lande handler i enighed. En fælles udenrigs- og sikkerhedspolitik er bragt et skridt nærmere.

- Adskillige europæiske landes store afhængighed af russisk energi er kommet i skarpt fokus. Det er blevet åbenbart, at der er tale om et sikkerhedspolitisk problem, og debatten om at mindske afhængigheden er begyndt.

- I mange hovedstæder børster man støvet af gamle forsvarsplaner og begynder at gå dem efter i sømmene. Herhjemme lyder de første krav om en ny forsvarskommission og en ny udenrigskommission.

Det er let at pege fingre af de modforholdsregler, Europa og USA har iværksat som reaktioner på Ruslands annektering af Krim-halvøen og det politiske og militære pres mod Ukraine.

Michael Ehrenreich er direktør for Det Udenrigspolitiske Selskab. 
Sanktionerne er blevet afvist som for få og for små og for virkningsløse. Men det glemmes ofte, at sanktioner begynder at virke længe inden, de iværksættes. Alene truslen om dem har betydelig effekt. Hvad det internationale erhvervsliv frygter allermest, er usikkerhed. Skabes der tvivl om de politiske rammevilkår, tøver man på direktionsgangene med at investere og engagere sig.

Lægges det hele sammen, er det tydeligt, at ledelsen i Kreml formentlig har overspillet sin hånd. På kort sigt ligner Putin en vinder, men i et længere perspektiv bliver der en meget høj pris at betale.

Som den tidligere tyske udenrigsminister Joschka Fisher gør opmærksom på i en af sine klummer på Det Udenrigspolitiske Selskabs hjemmeside, så har Rusland mere brug for EU end omvendt, fordi man mod øst og i Centralasien har Kina som en rival af helt andre dimensioner." I stedet har Putin nu udløst en vedvarende krise. Vestens svar bliver en ny inddæmningspolitik, hovedsageligt i form af økonomiske og diplomatiske skridt. Europa vil reducere sin afhængighed af energi fra Rusland, ændre sit strategiske syn og sine prioriteringer og reducere investeringer og bilateralt samarbejde", skriver Fischer.

Skal EU-samarbejdet fortsætte ad de nye spor, som nu lægges, kræver det, at EU ændrer sin egen selvopfattelse og endegyldigt forlader konceptet om "blot" at være et økonomisk samarbejde om et fælles marked.

Der skal fokuseres på helt anderledes slagkraftige politiske begreber som værdier, fælles sikkerhedsinteresser og strategiske interesser. Ifølge Joschka Fischer må europæerne i lyset af de nye trusler indse, at EU er en global spiller, der ikke bare kan ignorere omverdenen.I en geopolitisk forstand giver synspunktet god mening. Tidligere tiders satsning på, at USA vil varetage Europas udenrigs- og sikkerhedspolitiske interesser holder ikke længere, og selv under den nuværende krise har præsident Obama tilkendegivet, at amerikanerne forventer et stærkere europæisk internationalt engagement, end man har været vant til.Men de europæiske regeringer begår en stor fejl, hvis EU-samarbejdet udvikles til en endnu mere fasttømret politisk enhed - med alt hvad det indebære - uden at man får befolkningerne med sig.

Sporene fra tidligere årtiers "unionsbyggeri” skræmmer. At man dengang ikke fik sagt højt og tydeligt, så det kunne høres, hvad formålet var, og hvad konsekvenserne ville blive, er en af hovedårsagerne til den tillidskrise, som EU befinder sig i.

Krisen om Ukraine udfordrer vores europæiske idealer om fred, frihed, national selvbestemmelse og respekt for international lov og orden. Derfor er det mærkeligt, at krisen i skrivende stund ikke spiller nogen hovedrolle i valgkampen forud for valget til EuropaParlamentet.Det er, som om de grundlæggende ændringer i det europæiske sikkerhedspolitiske billede, der er sket, udfolder sig i et særligt rum, adskilt fra vores europæiske, politiske virkelighed.Man kan dårligt forlange, at de europæiske vælgere selv skal skabe sig et overblik og se sammenhængen. Det er en politisk opgave, og det kan jo nås endnu inden valgdagen. Men det er ved at være sidste udkald. 